\title{
Comprehensive Evaluation on the Control of Smart Distribution Network Project Investment Based on Cooperation Management during the Construction Process
}

\author{
Zhang Shuangying ${ }^{1, a}$, Liu Dunnan $^{2, b}$, Ju Song $^{1}$, Ji Lihang $^{2},{\text { Pan } \text { Jin }^{1}}^{1}$ \\ ${ }^{1}$ State Grid Liaoning Economic Research Institute, Liaoning, Shenyang, China, 110015; \\ ${ }^{2}$ North China Electric Power University, School of Economy and Management, Beijing, China, \\ 102206 \\ a490935411@qq.com, 'bliudunnan@163.com
}

\begin{abstract}
Keywords: cooperation management ; smart distribution network ; construction process ; investment control; investors; comprehensive evaluation

Abstract. This paper mainly have a comprehensive evaluation on the control of smart distribution network project investment during the construction process from the term of investors. First, according to the cooperation management, analyze the demand of investors' investment control, build the index system of comprehensive evaluation on the Control of Smart Distribution Network Project Investment. Second, build up a universal model of Comprehensive Evaluation on the Control of Smart Distribution Network Project Investment. Finally, test and verify the model, theory and method, showing the process of evaluating the investment control and determination of results.
\end{abstract}

\section{Introduction}

With the development of smart grid, distribution network intelligent has become true, therefore, the quantity of construction of smart power distribution network project is become more and more. However, due to the large number of smart distribution network construction, wide coverage, large investment, long construction period and there are many participants [1], the management of the intelligent distribution network construction work put forward very high requirements. The whole process of intelligent power distribution network management work is a lack of necessary supervision and evaluation mechanism [2], so it can not guarantee the reasonable control of the government investment funds.

In this paper, analyzes the government departments of the intelligent distribution network project management mode; secondly, establish the evaluation index system and evaluation model; finally, the process of comprehensive evaluation for the intelligent distribution network of engineering construction investment control of collaborative management model.

\section{The collaborative management theory of the intelligent distribution network engineering} construction investment control

Intelligent distribution network of the project investment is the government or enterprise or business unit, therefore, it belongs to the non operating government investment projects needing to achieves real-time supervision, collaborative management, to improve the efficiency of government supervision fundamentally, protect the investment value of non operational government investment projects and the construction of the target [3].

3 comprehensive evaluation index of investment control in the construction of intelligent power distribution network project based on collaborative management

\subsection{Building steps}

(1) Select the target

The determination of the target is the primary link to construct the index system, and the evaluation index is a kind of the decision maker to the target. To determine the target and gives the 
feasible category, and to make a comprehensive analysis of the factors of evaluation program, to make the evaluation effective.

(2) Set the indicator primary set

(1)Analysis of the subject. From the project life cycle, collaborative management, investment monitoring points, etc., to determine the evaluation objectives.

(2)Concept decomposition. Target decomposition is to get a series of related concepts, and further to do related concept decomposition, and finally to determine the accuracy of the target set of indicators.

(3)Logical structure analysis. After the index is determined, the relationship between the index and the target is analyzed, and the evaluation index system of the initial investment control is obtained.

(3) Indicator selection

The establishment of index system should be comprehensive and effective evaluation index. Although it has been considered as possible to achieve the full, it is possible to make some mistakes and repeat the selection, so we must screen the index.

(4) Index system construction

After factor analysis, the comprehensive evaluation index system of investment control in the construction of intelligent distribution network project based on collaborative management is constructed.

\subsection{Constructing index system}

According to the definition of coordination management, the project construction period of the cooperative management, mainly from the investors. Therefore, the investors' investment in the total control plan and the use of funds in the power grid project construction investment control is essential and based on that to build a comprehensive evaluation index system.

According to the power grid project WBS division and investment master plan, specific power grid construction project investment control based on collaborative management comprehensive evaluation index system are shown in table 1.

Table 1 Based on the collaborative management of power grid construction project investment control First grade indexes Second grade indexs

\begin{tabular}{cc}
\hline First grade indexes & Second grade indexs \\
\hline $\begin{array}{c}\text { General contract pay monitory point } \\
\text { of investment A }\end{array}$ & $\begin{array}{c}\text { Substation main equipment installation engineering cost A1 } \\
\text { Substation aided equipment installation engineering cost A2 } \\
\text { Subsystem debugging and whole set starting operation cost A3 } \\
\text { Substation main structure building project construction cost A4 } \\
\text { Substation housing construction engineering cost A5 } \\
\text { Transmission lines construction cost A6 } \\
\text { Barallel to the contract pay monitory } \\
\text { point of investment B }\end{array}$ \\
$\begin{array}{c}\text { Investors appointed subcontract engineering cost B8 } \\
\text { Investors appointed supplying and purchase cost B9 }\end{array}$ \\
\hline Project construction technology service C10 \\
Measure expense C11 \\
The investors paid directly monitory \\
point of investment C \\
Production preparation cost C12 \\
Management and supervision cost C13 \\
three accesses and site leveling cost C14 \\
Government charges C15 \\
Land expenses C16 \\
Other charges C17
\end{tabular}

\section{Comprehensive evaluation model of investment control in power grid project construction based on Collaborative Management}

In the comprehensive evaluation of power grid project construction investment control, the following process can be carried out:

(1)Determine the weight of each indicator

1) To determine the initial weights of the evaluation indexes by experts; 
2) Calculate the investment bias on the investment monitoring points, respectively, $i=1,2, \ldots$, the judgment matrix is shown in the formula (1):

$W=\left(w_{1}, w_{2}, w_{3}, w_{4}, w_{5}, w_{6}, w_{7}, w_{8}, w_{9}, w_{10}, w_{11}, w_{12}, w_{13}, w_{14}, w_{15}, w_{16}, w_{17}\right)^{T}$

(2)Determination of technical standards for benchmarking

0 as the highest evaluation standard, the other grades P1, P2, P3.

(3)Comprehensive evaluation

Using $a_{i j}$ to express the results of the expert $\mathrm{i}$ to evaluate the index $\mathrm{j}$, and getting the evaluation matrix (2):

$$
A=\left(\begin{array}{cccc}
a_{1,1} & a_{1,2} & \cdots & a_{1,17} \\
a_{2,1} & a_{2,2} & \cdots & a_{2,17} \\
\vdots & \vdots & \ddots & \vdots \\
a_{n, 1} & a_{n, 2} & \cdots & a_{n, 17}
\end{array}\right)
$$

The evaluation results for various experts:

$$
\mathrm{R}=\mathrm{A} \bullet \mathrm{W}=\left(\begin{array}{cccc}
\mathrm{a}_{1,1} & \mathrm{a}_{1,2} & \cdots & \mathrm{a}_{1,17} \\
\mathrm{a}_{2,1} & \mathrm{a}_{2,2} & \cdots & \mathrm{a}_{2,17} \\
\vdots & \vdots & \ddots & \vdots \\
\mathrm{a}_{\mathrm{n}, 1} & \mathrm{a}_{\mathrm{n}, 2} & \cdots & \mathrm{a}_{\mathrm{n}, 17}
\end{array}\right) \bullet\left(\begin{array}{c}
w_{1} \\
w_{2} \\
\vdots \\
w_{17}
\end{array}\right)=\left(\begin{array}{c}
\mathrm{a}_{1,1} \bullet w_{1}+\mathrm{a}_{1,2} \bullet w_{2}+\cdots+\mathrm{a}_{1,17} \bullet w_{17} \\
\cdots \\
\cdots \\
\mathrm{a}_{\mathrm{n}, 1} \bullet w_{1}+\mathrm{a}_{\mathrm{n}, 2} \bullet w_{2}+\cdots+\mathrm{a}_{\mathrm{n}, 17} \bullet w_{17}
\end{array}\right)=\left(\begin{array}{c}
r_{1} \\
r_{2} \\
\vdots \\
r_{n}
\end{array}\right)
$$

Among them:

$$
r_{i}=a_{i, 1} \bullet w_{1}+a_{i, 2} \bullet w_{2}+\cdots a_{i, 17} \bullet w_{17}
$$

The comprehensive evaluation results for the investment control:

$$
R=\left|\frac{1}{n} \sum_{i=1}^{n} r_{i}\right|
$$

According to the evaluation results of the applicability of the technical standards can be divided into different levels of technical standards, classified according to the following table:

Table 2 Suitability evaluation scale

\begin{tabular}{c|cccc}
\hline Score & $\mathrm{R} \leqslant \mathrm{P} 1$ & $\mathrm{P} 1<\mathrm{R} \leqslant \mathrm{P} 2$ & $\mathrm{P} 2<\mathrm{R} \leqslant \mathrm{P} 3$ & $\mathrm{P} 3<\mathrm{R}$ \\
Control the result & Good & Average & Weak \\
$\begin{array}{c}\text { Completion and } \\
\text { acceptance situation }\end{array}$ & $\begin{array}{c}\text { Acceptance, } \\
\text { reward }\end{array}$ & $\begin{array}{c}\text { Agree to } \\
\text { acceptance }\end{array}$ & $\begin{array}{c}\text { To find a reasonable } \\
\text { reason, can check and } \\
\text { accept }\end{array}$ & $\begin{array}{c}\text { Investigate the } \\
\text { responsible of } \\
\text { excess }\end{array}$ \\
\hline
\end{tabular}

\section{Empirical Analysis}

Taking a power grid engineering project as an example, the comprehensive evaluation of investment control is carried out.

(1)To determine the investment deviation rate of the various investment monitoring points of the power grid project, seeing the table 3;

Table 3 A power grid construction project investment control deviation of comprehensive evaluation index

\begin{tabular}{ccc}
\hline First grade indexs & Second grade indexs & Deviation (\%) \\
\hline & Substation main equipment installation engineering cost A1 & 2 \\
General contract pay & Substation aided equipment installation engineering cost A2 & 3 \\
monitory point of & Subsystem debugging and whole set starting operation cost A3 & 1 \\
investment A & Substation main structure building project construction cost A4 & -2 \\
& Substation housing construction engineering cost A5 & -1 \\
\hline & Transmission lines construction cost A6 & 2 \\
\hline
\end{tabular}




\begin{tabular}{ccc}
\hline \multirow{2}{*}{$\begin{array}{c}\text { Parallel to the contract pay } \\
\text { monitory point of } \\
\text { investment B }\end{array}$} & Basis construction cost A7 & 3 \\
& Investors appointed subcontract engineering cost B8 & -2 \\
& Investors appointed supplying and purchase cost B9 & -1 \\
The investors paid directly & Project construction technology service C10 & -1 \\
monitory point of & Measure expense C11 & 2 \\
investment C & Production preparation cost C12 & 0 \\
& Management and supervision cost C13 & 1 \\
& three accesses and site leveling cost C14 & 0 \\
Government charges C15 & 3 \\
\hline
\end{tabular}

It is concluded that judgment matrix:

$$
W=(2,3,1,-2,-1,2,3,-2,-1,-1,2,0,1,0,3,4,1)^{T}
$$

According to experts' table 4, forming the evaluation matrix:

Table 4 Expert rating of the index weight

\begin{tabular}{|c|c|c|c|c|c|c|c|c|c|c|c|c|}
\hline $\begin{array}{l}\text { First grade } \\
\text { indexs }\end{array}$ & Second grade indexs & 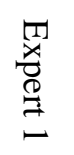 & 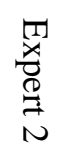 & 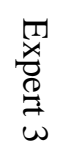 & 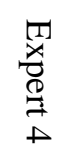 & 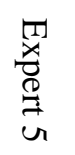 & 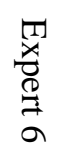 & 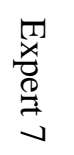 & 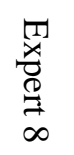 & 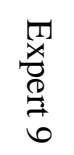 & 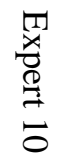 & 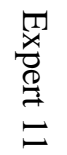 \\
\hline \multirow{7}{*}{$\begin{array}{c}\text { General } \\
\text { contract pay } \\
\text { monitory point } \\
\text { of investment A }\end{array}$} & $\begin{array}{c}\text { Substation main } \\
\text { equipment } \\
\text { installation } \\
\text { engineering cost A1 }\end{array}$ & 0.8 & 0.8 & 0.7 & 0.8 & $\begin{array}{c}0.7 \\
5\end{array}$ & 0.8 & 0.9 & 0.8 & 0.7 & 0.7 & 0.6 \\
\hline & $\begin{array}{l}\text { Substation aided } \\
\text { equipment } \\
\text { installation } \\
\text { engineering cost A2 }\end{array}$ & 0.7 & 0.8 & 0.8 & 0.7 & 0.7 & 0.9 & 0.7 & 0.8 & 0.7 & 0.7 & 0.6 \\
\hline & $\begin{array}{l}\text { Subsystem } \\
\text { debugging and whole } \\
\text { set starting operation } \\
\text { cost A3 }\end{array}$ & 0.4 & 0.4 & 0.4 & 0.3 & 0.4 & 0.4 & 0.3 & 0.3 & 0.4 & 0.4 & 0.4 \\
\hline & $\begin{array}{l}\text { Substation main } \\
\text { structure building } \\
\text { project construction } \\
\text { cost A4 }\end{array}$ & 0.5 & 0.6 & 0.4 & 0.7 & 0.5 & 0.6 & $\begin{array}{c}0.5 \\
5\end{array}$ & 0.7 & 0.7 & 0.6 & 0.6 \\
\hline & $\begin{array}{l}\text { Substation housing } \\
\text { construction } \\
\text { engineering cost A5 }\end{array}$ & 0.7 & 0.8 & 0.6 & 0.9 & 0.6 & 0.7 & 0.8 & 0.7 & 0.6 & 0.7 & 0.6 \\
\hline & $\begin{array}{l}\text { Transmission lines } \\
\text { construction cost A6 }\end{array}$ & 0.7 & 0.7 & 0.8 & 0.7 & 0.8 & 0.6 & 0.8 & 0.6 & 0.7 & 0.5 & 0.8 \\
\hline & $\begin{array}{c}\text { Basis construction } \\
\text { cost A7 }\end{array}$ & 0.6 & 0.5 & 0.6 & 0.7 & 0.5 & 0.6 & 0.6 & 0.5 & 0.6 & 0.7 & 0.6 \\
\hline $\begin{array}{l}\text { Parallel to the } \\
\text { contract pay }\end{array}$ & $\begin{array}{l}\text { Investors appointed } \\
\text { subcontract } \\
\text { engineering cost B8 }\end{array}$ & 0.5 & 0.6 & 0.7 & 0.6 & 0.5 & 0.7 & 0.5 & 0.6 & 0.6 & 0.7 & 0.5 \\
\hline $\begin{array}{l}\text { monitory point } \\
\text { of investment B }\end{array}$ & $\begin{array}{l}\text { Investors appointed } \\
\text { supplying and } \\
\text { purchase cost B9 }\end{array}$ & 0.7 & 0.9 & 0.7 & 0.8 & 0.6 & 0.8 & 0.7 & 0.6 & 0.9 & 0.8 & 0.8 \\
\hline \multirow{4}{*}{$\begin{array}{l}\text { The investors } \\
\text { paid directly } \\
\text { monitory point } \\
\text { of investment C }\end{array}$} & $\begin{array}{l}\text { Project construction } \\
\text { technology service } \\
\text { C10 }\end{array}$ & 0.4 & 0.9 & 0.8 & 0.6 & 0.7 & 0.4 & 0.5 & 0.6 & 0.9 & 0.7 & 0.8 \\
\hline & $\begin{array}{c}\text { Measure expense } \\
\text { C11 }\end{array}$ & 0.4 & 0.5 & 0.3 & 0.6 & 0.4 & 0.5 & 0.3 & 0.5 & 0.6 & 0.4 & 0.5 \\
\hline & $\begin{array}{c}\text { Production } \\
\text { preparation cost } \mathrm{C} 12\end{array}$ & 0.2 & 0.3 & 0.4 & 0.4 & 0.3 & 0.5 & 0.4 & 0.3 & 0.5 & 0.4 & 0.4 \\
\hline & $\begin{array}{l}\text { Management and } \\
\text { supervision cost C13 }\end{array}$ & 0.4 & 0.5 & 0.6 & 0.6 & 0.7 & 0.5 & 0.5 & 0.4 & 0.5 & 0.6 & 0.4 \\
\hline
\end{tabular}




\begin{tabular}{cccccccccccc}
$\begin{array}{c}\text { three accesses and } \\
\text { site leveling cost C14 }\end{array}$ & 0.5 & 0.5 & 0.6 & 0.6 & 0.5 & 0.6 & 0.7 & 0.4 & 0.5 & 0.6 & 0.4 \\
Government charges & 0.8 & 0.8 & 0.7 & 0.6 & 0.8 & 0.9 & 0.6 & 0.8 & 0.5 & 0.7 & 0.8 \\
C15 & & & & & & & & & & \\
Land expenses C16 & 0.7 & 0.6 & 0.6 & 0.5 & 0.7 & 0.6 & 0.4 & 0.6 & 0.8 & 0.5 & 0.6 \\
Other charges C17 & 0.4 & 0.5 & 0.5 & 0.4 & 0.6 & 0.4 & 0.6 & 0.5 & 0.5 & 0.6 & 0.4 \\
\hline
\end{tabular}

(3)Calculate the evaluation results to:

$$
\mathrm{R}=9.3
$$

Table 5 Marking table

\begin{tabular}{c|cccc}
\hline Score & $\mathrm{R} \leqslant 5$ & $5<\mathrm{R} \leqslant 102$ & $10<\mathrm{R} \leqslant 123$ & $12<\mathrm{R}$ \\
Control the result & Excellent & Good & Average & Weak \\
$\begin{array}{c}\text { Completion and } \\
\text { acceptance situation }\end{array}$ & $\begin{array}{c}\text { Acceptance, } \\
\text { reward }\end{array}$ & $\begin{array}{c}\text { Agree to } \\
\text { acceptance }\end{array}$ & $\begin{array}{c}\text { To find a reasonable reason, } \\
\text { can check and accept }\end{array}$ & $\begin{array}{c}\text { Investigate the } \\
\text { responsible of excess }\end{array}$ \\
\hline
\end{tabular}

The project investment control results is good, agreed to acceptance, belonging to the qualified project from the table 5 .

\section{Conclusions}

In this paper, based on the investor of power grid project, in view of the collaborative management of power grid project investment control, to establish the evaluation index system, and adopt the method of comprehensive evaluation, to evaluate the investment control level, it is benefit for the investor to effectively control project investment and divide the responsibility.

\section{References}

[1] Hui Chen. Research on Cost Control of Distribution Network Engineering Project [D]. North China Electric Power University, 2013.

[2] Jiawei Sun. Study on the Construction of Smart Distribution Power Grid in Core Area of Baoding City [D]. North China Electric Power University, 2014.

[3] Yunna Wu,Yong Huang. Non-operating government investment project coordinated regulation theory and method [M]. North China electric power university, 2012. 